\title{
EL FLÂNEUR Y LA FLANERIE EN LAS CRÓNICAS MODERNISTAS LATINOAMERICANAS: JULIÁN DEL CASAL, AMADO NERVO, JOSÉ MARTÍ, MANUEL GUTIÉRREZ NÁJERA Y ARTURO AMBROGI
}

\author{
Dorde Cuvardic García
}

\begin{abstract}
RESUMEN
Enrique Gómez Carrillo y Rubén Darío se erigen como los principales representantes de la flanerie en el modernismo latinoamericano. En todo caso, otros autores de este periodo estético realizaron contribuciones ocasionales a esta práctica cultural: Manuel Gutiérrez Nájera, Amado Nervo, Julián del Casal, José Martí, José Enrique Rodó, Arturo Ambrogi... Estos últimos escritores elaboran textos de la flanerie clásica: apreciación del espacio callejero como teatro social, utilización de la técnica descriptiva de la escena o cuadro, interés por los espacios comerciales o las festividades públicas... En todo caso, también nos enfrentamos a disidencias ideológicas, Así, Julián del Casal, como decadentista, asume una actitud desengañada y aristocrática frente al espacio público y su utilitarismo capitalista. Por su parte, algunas crónicas urbanas de Martí materializan la dialéctica entre la seducción que provoca el progreso norteamericano y el repudio de sus valores, opuestos al 'alma' latina.

Palabras clave: Flâneur, flanerie, modernismo, modernidad, crónicas.
\end{abstract}

\begin{abstract}
Flanerie finds in Enrique Gómez Carrillo and Rubén Darío two of its best examples in Latin American Modernism. However, Manuel Gutiérrez Nájera, Amado Nervo, Julián del Casal, José Martí, José Enrique Rodó and Arturo Ambrogi also produced texts depicting classic flanerie such as watching urban spaces as social theater, creating pintoresque escenarios or cuadros, or focusing on commercial spaces or public festivities. As a decadent, Julian del Casal, represents an aristocratic and dissenchanted perspective, whereas Marti is a clear example of the paradox between acknowledging American progress and the rejection of their moral values, in contradiction against the latino soul.

Key words: Flâneur, flanerie, modernism, modernity, crhronicles.
\end{abstract}

\section{Introducción}

El flâneur puede ser entendido como categoría histórica (el paseante burgués o pequeño burgués de los pasajes en la década de 1830 en París), o como categoría conceptual que permite

Dr. Dorde Cuvardic García. Profesor de la Escuela de Filología, Lingüística y Literatura. Universidad de Costa Rica.

Correo electrónico:dcuvardic@yahoo.es

Recepción: 13- 09- 2010

Aceptación: 20- 10 -2010 
identificar diversas modalidades de observación callejera, sin depender de coordenadas espaciotemporales específicas (Tester 1994: 16). Numerosos analistas, entre ellos Neumeyer (1999), asumen este segundo acercamiento, que suscribimos en el presente caso ${ }^{1}$. Podemos hablar de distintos tipos de callejeos, como los emprendidos por el flâneur costumbrista, el modernista, el impresionista, el expresionista, el existencialista, etc. Permanece el núcleo conceptual en todas estas experiencias: el flâneur es un observador reflexivo de la urbe.

En este artículo, analizamos al flâneur modernista, específicamente, el latinoamericano. Como voz enunciativa, encontró canal de expresión en la literatura en la crónica, género importado de Francia entre 1875 y $1880^{2}$, aunque podemos ubicar importantes precedentes, como Las conversaciones del domingo (1868), de Justo Sierra, y Las crónicas de la semana (1869), de Ignacio Manuel Altamirano, como se encarga de señalar Martínez (1997: 209-210). Tampoco debemos obviar que, cuando utiliza la modalidad de la escena urbana (ya que también puede emplear procedimientos como la semblanza, el comentario de la actualidad, etc.), la crónica modernista adopta muchos procedimientos del cuadro costumbrista, entre ellos la perspectiva distanciada del flâneur.

Nos dedicamos en el presente artículo a indagar la presencia de la flanerie en la producción de autores modernistas que, por lo general, no han sido asociados a la retórica del callejeo: Julián del Casal, Amado Nervo, José Martí, Manuel Gutiérrez Nájera y Arturo Ambrogi. Buscamos responder a la siguiente pregunta: ¿Utilizan las crónicas de estos autores estrategias enunciativas y referenciales típicas de la flanerie urbana?

\section{La flanerie en Julián del Casal}

Entre los numerosos escritores modernistas que redactaron crónicas periodísticas se encuentra Julián del Casal (1863-1893). El objetivo del presente apartado es analizar la presencia de la retórica de la flanerie en las crónicas de este último escritor ${ }^{3}$.

A pesar de la presencia de esta retórica en sus crónicas, las investigaciones publicadas hasta ahora no han trabajado en esta línea de investigación. Así, por ejemplo, Federman (1975) analiza la presencia decadentista en algunas crónicas de Casal. Sólo se discute brevemente la presencia de la flanerie en una de las más conocidas crónicas de Julián del Casal, Álbum de la ciudad. El Fénix. Es el caso de Montero (1993: 79-86), quien encuentra una evolución en la actitud del cronista hacia este almacén de novedades. Al inicio de la crónica se representa a sí mismo como paseante que, frente a la suciedad de las calles, motivo de su irritación nerviosa, queda atraído por los objetos de la tienda; en la aglomeración de productos -los significantes visuales (objetos) que la tienda ofrece-, rápidamente llega al agotamiento y al silencio; seguidamente, se enumeran -metonímicamente- los objetos de las tres partes de la tienda desde el hastío del consumo visual, consciente de la devaluación que tienen estas mercancías de 'lujo' producidas industrialmente; finalmente, reclamado por la calle, y ante la mirada deseante de unos niños pobres, el cronista toma conciencia del falso deslumbramiento producido por el espacio comercial. Es una de las escasas crónicas donde Casal toma conciencia de la solución vana que, para la conciencia del artista, supone el refugio en los espacios interiores. Decimos esto porque, por lo general, en las crónicas de Julián del Casal la calle es un espacio moral y físicamente 'sucio' del que es necesario huir.

El flâneur, en Julián del Casal, es decadentista. Se encuentra en el espacio público, por lo general, en actitud de hastío. Así se autorretrata el cronista en Croquis femenino (Fragmentos), que tiene el número LXXIII en la publicación de sus Obras completas en 1964: 
Muchos días, al caer la tarde, experimento el deseo de vagar solo por las calles lejanas, desiertas y silenciosas, donde no se escucha el ruido de los carruajes, donde no se encuentran ciertas gentes y donde las doncellas se asoman a las rejas de las ventanas, con el busto ornado de rosas y el abanico abierto, entre las manos, esperando al hombre que habrá de libertarlas de las tiranías paternales. Andando largo tiempo, los nervios se adormecen, el hastío se acerca y hasta se siente un poco más de amor a la humanidad. (1964: 125)

La expresión "experimento el deseo de vagar solo por las calles lejanas, desiertas y silenciosas" pertenece a las definiciones tradicionales de la flânerie, la actividad de caminar ociosamente sin objetivo predefinido. Interesa analizar el adormecimiento de los nervios que se presenta en esta crónica. Como ha analizado Crary (2008), las prácticas culturales de la modernidad decimonónica implican en la percepción del ciudadano un aumento de los centros de atención, que compiten entre sí; este proceso conduce, finalmente, al hastío. El enunciador de la crónica de Casal se refiere precisamente a aquel momento en el que la sobrecarga de estímulos ha adquirido tal magnitud que se llega a un nivel de saturación: las impresiones externas dejan de captar la atención y se llega al estado de hastío.

Aunque no tiene intereses definidos, el flâneur logra siempre observar algún personaje capaz de asumir como el objeto de la crónica y reconstruir, por medio de su método deductivo, la historia y los sentimientos que se esconden tras la fachada de los tipos sociales observados. En la mencionada Croquis femenino (Fragmentos), el narrador ve, tras las persianas de una casa sencilla, a una figura femenina de dudosa vida a la que conoce. El modelo es el poema en prosa Las ventanas, de Baudelaire. Una variante se encuentra en otro Croquis femenino, que lleva el número LXXXIII en las Obras completas publicadas en 1964. En este caso, el cronista encuentra a la mujer en un carruaje: "Viéndola pasar, por nuestras calles tumultuosas, reclinada muellemente sobre el cojín de raso negro, bordado de oro, que se destaca en uno de los ángulos de su carruaje elegante, diríase que es una Semíramis moderna derribada de su trono" (2002c: 207).

Interesa analizar el sustantivo presente en el título de ambas crónicas, croquis, que nos permite emprender un análisis perteneciente al ámbito de las relaciones entre la pintura y la literatura, exploradas por el modernismo latinoamericano. Podemos considerar que el croquis es un término que guarda semejanzas estéticas y enunciativas con el de escena o cuadro, que tanto ha contribuido a perfilar la representación urbana del flâneur. El flâneur-escritor prepara croquis, esbozos, cuadros, tableaux, de la calle. En estas circunstancias, el croquis literarioperiodístico, que se ocupa de la metamorfosis de las cosas exteriores, cumple la misma función en la representación de la modernidad urbana que las definidas por Baudelaire para el croquis de costumbres, en el ámbito de las artes visuales: "Para el croquis de costumbres, la representación de la vida burguesa y los espectáculos de la moda, el medio más expeditivo y menos costoso es el mejor. Cuanta más belleza ponga el artista, más preciosa será la obra; pero hay en la vida trivial, en la metamorfosis cotidiana de las cosas exteriores, un movimiento rápido que impone al artista la misma velocidad de ejecución" (Baudelaire 1996: 353). También aparece un caso de paralelismo entre el lenguaje pictórico y el literario en la crónica Agua fuerte. Media noche, donde se describen los trabajos de eliminación de escombros y de recuperación de cadáveres después de un incendio. El cronista, observador-testigo, se ocupa de la tragedia desde el distanciamiento estético, como si describiera un tenebroso aguafuerte.

Los espacios públicos también quedan representados por el flâneur en sendas crónicas dedicadas a la Nochebuena y a la Navidad. Este tema también ha sido representado, en la escritura modernista, por Gutiérrez Nájera y por Martí. En La Noche Buena, el cronista describe los almacenes de comestibles y la algarabía de las calles. Como es habitual tanto en el costumbrismo como en el modernismo, el centro de atención no son las actividades públicas, sino sus espectadores: 


\begin{abstract}
Pero el que más se divierte, en esta noche, es el pueblo bajo de la capital. Apenas ha oscurecido, no se puede transitar a pie por las calles. La turbas invaden las aceras, deteniéndose absortas ante las vidrieras de los establecimientos; agloméranse en las esquinas, temiendo ser atropelladas por los carruajes; penetran en las tabernas, atiborrándose de alcohol; entran en los teatros, dispuestas a interrumpir al actor en lo más culminante de su papel; y se refugian por último, en los templos católicos, donde escuchan la misa de media noche, no con místico recogimiento, sino con la curiosidad silenciosa de los que van a un espectáculo que sólo presencian anualmente una sola vez. (Casal 1964: 13)
\end{abstract}

El fetichismo de la mercancía, la atracción hacia las mercancías de lujo, y su equiparación con las bellezas de una mujer, se convierten en alegorías de la búsqueda inalcanzable del ideal de belleza por parte del artista. El producto del capitalismo, la mercancía, se coloca al servicio del elogio estético. Así ocurre en Japonería: "Dentro del escaparate de una tienda [...] he visto esta mañana, al salir de paseo, un búcaro japonés, digno de figurar en tu alcoba blanca" (Casal 1964: 97). Es clásica la figura del flâneur ante un escaparate, ya desde la escritura costumbrista francesa. En Japonería, el cronista apostrofa a una mujer para que coloque el búcaro donde no se escuchen las pisadas de sus adoradores o el sonido de los besos sensuales, porque, como dice el enunciador, "tu destino, como el de esa Quimera, te ha condenado a perseguir un ideal, tan alto y tan bello, que no lo podrás alcanzar jamás" (Casal 1964: 97). Tal pareciera que ocurre una identidad entre la mujer y el poeta, ambos en búsqueda de la inalcanzable perfección de la belleza artística.

En Bocetos Sangrientos. El matadero, el cronista se aleja del centro de la ciudad y de las mercancías de lujo y recorre la Otredad urbana. Casal no es el primer escritor latinoamericano en representar este espacio. El matadero, del escritor argentino costumbrista José Esteban Echevarría, se convirtió en alegoría de la 'barbarie' de los primeros años independientes de las repúblicas latinoamericanas. Al igual que el escritor argentino, Casal utiliza el procedimiento de la escena. Los espacios y las actividades del barrio donde se sitúa el matadero se describen desde las convenciones típicas de este procedimiento descriptivo, desde el punto de vista de un observador distanciado física y afectivamente de los acontecimientos. Además, el enunciador exhibe el recorrido de sus observaciones como si describiera paulatinamente una pintura (se fragmenta el espacio físico):

\footnotetext{
Atravesando un callejón anchuroso, quemado por los rayos de un sol de fuego, con los pies hundidos en blanda alfombra de polvo, pude contemplar varias cosas. A la derecha, una cuadrilla de presidiarios, [...] aprendían el oficio de picapedreros [...]. A la izquierda, bajo portales mugrientos, agujereados y apestosos, varios hombres robustos, cuchillo en mano y ensangrentadas las ropas, abrían, vaciaban y sumergían miembros de animales en altas latas de metal [...]. Un poco más lejos, a la orilla del río, se alineaban las barracas habitadas por las gentes del lugar, semejantes a islotes negruzcos en que han venido a refugiarse los supervivientes del naufragio social. (Casal 1964: 153)
}

La intencionalidad alegórica de Echeverría desaparece en la escena descrita por Casal, donde sólo impera una atracción morbosa por una práctica social, tipificada como espectáculo, alejada de los ideales estéticos del narrador. Como ejemplo, ofrecemos el final de la crónica: "Y tal es la sensación que produce el espectáculo, que todavía, al escribir estas líneas me parece hacerlo con sangre, entre sangre y con manos sanguinarias" (Casal 1964: 154).

Conocida es la recreación de La Habana, en Casal, como ciudad invernal. Es el caso de la Sección I, de la crónica Frío, de Álbum de la ciudad. Después del ocaso, el frío queda personificado como enemigo a combatir:

Desde la puesta del sol, el silencio se difunde por las calles. No se oye más que el rodar de los coches, el silbido de los ómnibus y la vibración de alguna campana. Los transeúntes, calado el sombrero hasta las orejas, metidas las manos en los bolsillos, alzado el cuello de terciopelo del gabán, son cada vez más raros. Ninguno se detiene un instante. Todos marchan deprisa, como si temieran llegar tarde a una cita 
[...] Quiere penetrar a la fuerza en todas partes. Pero se le da con la puerta en las narices. Entonces se queda solo en las calles, haciéndonos desertar de ellas porque nos obliga a refugiarnos en algún café, en algún salón o en algún teatro. (Casal 1964: 67)

En todo caso, silencio y frío son valores positivos para el antihéroe modernista, al igual que la lluvia. Se disfrutan desde el refugio del hogar. En la crónica Bajo la lluvia, este fenómeno atmosférico permite tomar conciencia de la protección del interior burgués: "La lluvia nos liberta de muchas molestias que, al cabo del día, nos incapacitan para muchas cosas. Mientras está cayendo no se escucha el tic-tac de los relojes, ni el estrépito de los carretones, ni la voz de los billeteros, ni los campanillazos de los ómnibus" (Casal 2002b: 194). Pero también el cronista disfrutará ocasionalmente de la lluvia si sale a la calle. Los transeúntes desprecian la lluvia porque interfiere en sus actividades prácticas; el flâneur, en cambio, la elogia porque le permite reconfigurar la realidad desde su ideal, desde la imaginación poética:

\footnotetext{
¿Habrá noches más bellas que las noches lluviosas? Si se sale a la calle, mientras se halla un coche, las gotas de agua que recibimos nos producen estremecimientos voluptuosos; si se va al teatro, como hay poca gente, se oye mejor a los actores...[...] y si se mira al cielo, el disco amarillo de la luna, oculto entre nubes negras, corriendo por los espacios celestes, semeja el rostro lívido de una belleza celosa. (Casal 2002b: 195)
}

De nuevo, típico en Casal, la belleza femenina es alegoría del Arte. La facultad que activa, como escritor que trabaja en la tradición romántica del genio poético, es la imaginación. Pero una vez que termina de llover, su efecto poético se disuelve. La experiencia visionaria sólo se vislumbra momentáneamente. El poeta debe regresar a la fealdad de la urbe y comprobar sus devastadores efectos materiales:

\footnotetext{
Ya las últimas gotas se desprenden de los hilos telegráficos, como brillantes desmontados de un collar; y las losas de las aceras se ennegrecen, como espejos empañados; ya los trenes retornan a la ciudad, como heraldos de nuevas desgracias, trayendo noticias de los males espantosos que la lluvia ha causado en nuestros campos desiertos, inundados, silenciosos. (Casal 2002b: 196)
}

El espacio público, para Casal, es ambivalente. A veces, emprende la flanerie con el objetivo de encontrar el ideal de Belleza que anhela. En otras ocasiones, es el espacio de la fealdad prosaica de la que pretende huir, fealdad a la que pertenece la multitud, entidad a la que otros cronistas modernistas se sienten atraídos, como Martí (en la modernidad tecnológica estadounidense) o Gómez Carrillo (en el 'encanto' de las ciudades europeas o de Buenos Aires). De esta manera, la crónica El circo oriental supone el relato de los motivos que ofrece el cronista a sus lectores para no asistir a la función circense que en principio iba a describir:

\footnotetext{
Abierto el circo, la muchedumbre se desbordó, como impetuoso torrente, por el interior de él [...] Pasados unos momentos, traté de entrar. Pero todo fue en vano. Además de la aglomeración de gentes [...] se respiraba una atmósfera malsana [...] Durante el día de ayer, ha habido dos funciones en el Circo Oriental que no he logrado presenciar. Había tanta gente como en noches anteriores. (Casal 1964: 121-122)
}

Por otra parte, sólo la necesidad de entregar una crónica y de suponer una experiencia inédita le incita a visitar el Matadero, en la crónica del mismo nombre, "(c)ansado de recorrer la población, buscando algo nuevo que admirar" (Casal 1964: 153). Estamos ante un cambio de paradigma: por primera vez, el flâneur, en el decadentismo, en lugar de sentirse atraído por el baño de multitudes, una de sus funciones clásicas en las estéticas costumbrista o impresionista, preferirá en cambio, el silencio, la soledad y la reclusión. 


\section{La flanerie en Amado Nervo}

Amado Nervo (1870-1919) cuenta con bastantes crónicas urbanas donde se utiliza la mirada del flâneur. Incluso en una ocasión, en la crónica El que viene, la descripción de la actividad callejera participa de las clásicas definiciones de la flanerie: "Yo, que gusto tanto de mezclarme a este trajín ensordecedor de la vida moderna, con tal de poder tornar a mi soledad así que me plazca, he recorrido algunas veces, mientras se desvanecen las tardes, las empinadas callejuelas de ciertos barrios, del de Segovia, por ejemplo" (Nervo 1946: 59). Aquí se identifica tanto con el flâneur baudelaureano que se sumerge en la multitud como con aquel que pretende recuperar la memoria de la ciudad al deambular por las olvidadas callejuelas del casco histórico (Franz Hessel; Apollinaire).

Muchas de sus crónicas urbanas representan y evalúan los espacios públicos de las ciudades americanas y europeas desde la mirada del observador. Así, por ejemplo, en la crónica sin título publicada en el periódico La semana el 17 de abril de 1905 se procede a la descripción de una mañana. El estilo es impresionista, centrado en los sonidos:

\footnotetext{
¡Viernes de Dolores! La mañana es luminosa. El sol enrojece los semblantes. Envuelta en el júbilo primaveral, esta bulliciosa ciudad de México parece más alegre aún que de ordinario. El campanilleo de los tranvías eléctricos, el incesante rodar de los vehículos, los mil gritos de la calle, toda esa sinfonía de la vida diaria suena más atolondrada bajo la ardiente sonrisa matinal. ${ }^{4}$ (La cursiva es añadida. Nervo 1971: 130)
}

Interesa reflexionar sobre el concepto de sinfonía urbana: la actividad callejera percibida por el oído, descrita retóricamente desde el procedimiento de la acumulación caótica, se interpreta como la sinfonía de la vida callejera. Debería realizarse un estudio arqueológico de este término musical. Recuérdese que se utiliza para tipificar el género cinematográfico del documental urbano vanguardista de los años 20 (por ejemplo, Berlín, Sinfonía de una gran ciudad, de 1927). Nervo también lo utiliza. Es muy posible que ya desde la segunda mitad del siglo XIX fuera un término empleado para tipificar las diversas variaciones en la intensidad de la actividad pública diaria de las ciudades.

Las transformaciones del espacio arquitectónico siempre han interesado a los escritores. Bécquer, por ejemplo, fue un gran defensor de este patrimonio. Baudelaire, asimismo, lamentó las reformas realizadas en París por el Barón de Haussmann. No siempre sucede así. Algunos cronistas, como Gutiérrez Nájera (véase el apartado correspondiente en este mismo artículo) respaldan la eliminación de los barrios antiguos por motivos de higiene. Por su parte, Nervo, en la crónica sin título publicada en La Semana el 26 de junio de 1905, no lamenta el derribo de un convento que, víctima de la desamortización, se había convertido en una cuadra. La higiene es el principal motivo de la defensa de las transformaciones urbanísticas liberales:

\footnotetext{
La vieja calle de Santa Clara se moderniza a ojos vista y aquellos escarpados muros de tezontle, agujereados por algunas ventanas estrechas, eran un adefesio. [...] la ciudad moderna demanda su sitio, su espacio, el lugar que le corresponde en estas perennes alternativas de la vida, y los muros seculares caen con ruido seco, y la luz impaciente se cuela por todas partes, con la alegría de no encontrar ya aquellas piedras taimadas que por tanto tiempo le estorbaron el paso...(139)
}

Otro ejemplo de evaluación positiva del progreso y de su incidencia en las transformaciones urbanísticas se encuentra en la crónica sin título publicada en La semana el 3 de julio de 1905, dedicada a la inauguración del tranvía de Atzcapotzalco, que favorece la urbanización de nuevos terrenos. El cronista lo considera el novísimo ideal del más grande México: "Cada pueblecillo del distrito que por la vía eléctrica queda unido a la capital, se constituye en un verdadero barrio de ésta. La fiebre de construcción que nos devora se 
exacerba, y en un instante los huecos se llenan, desaparecen los baldíos, y las casitas de todos los estilos asoman entre los árboles" (143). El cronista flâneur, en este sentido, se convierte, ante los lectores, en testigo de la eficacia de una modernidad centrada en la planificación urbanística y el fomento de las vías de comunicación.

Momentos puntuales del espacio público callejero (amanecer, medio día, ocaso, horas de intenso tráfico) siempre han formado parte de las representaciones del periodismo urbano. Las tres de la mañana encuentra una evaluación comparativa de las ciudades de París y Madrid en la crónica Noches blancas y días bermejos los que han matado al sueño. A esta hora, París llega a su único momento de reposo, cuando las últimas actividades del día anterior han concluido y no han iniciado las más tempranas del día siguiente. Por el contrario, el espacio público de Madrid se encuentra en este momento en plena actividad (el cronista generaliza para la totalidad de Madrid sus observaciones de la Puerta del Sol):

\footnotetext{
París tiene un momento de reposo, aun en el corazón mismo de la inmensa capital./ Hay un instante, a eso de las tres de la mañana, cuando los trasnochadores se acuestan y los madrugadores no se levantan aún, cuando se cierran los últimos (o, si ustedes gustan, los penúltimos) cafés y no empieza aún el rodar de los carros que surten los mercados centrales; hay un momento, digo, en que el monstruo se aletarga. / En Madrid no pasa esto. Madrid no se aletarga, no dormita jamás. O es acaso como uno de esos gigantes de los cuentos, que duermen con sólo un ojo./ A las tres de la mañana, el habitual escenario de la Puerta del Sol está en plena animación. Infinidad de grupos hablan de política [...]; los cafés están henchidos de parroquianos, resonantes de risas, charlas, gritos, y ruedan por todas las calles los coches que conducen a sus casas a los que vuelven de una comida, de una visita o de un club. (159-160)
}

Frente a la aletargada vida madrileña descrita por Rubén Darío en España contemporánea o por Enrique Gómez Carrillo en La miseria de Madrid, se eleva el vitalista espacio público de la capital española propuesto por el enunciador de la crónica de Nervo.

La grata sorpresa del dinamismo madrileño se convierte en admiración hacia la capital británica en De Liverpool a Londres a las puertas de la gran Babilonia. Al igual que Enrique Gómez Carrillo en su visita a San Petersburgo, Nervo llega a la ciudad en tren. Lo primero que se aprecia es la fachada arquitectónica:

\begin{abstract}
Ante el ojo rectangular de este arco se extiende la perspectiva de una gran avenida solitaria, flanqueada de altas casas de ladrillo, de algunas iglesias y de varios parques. A lo lejos, a la luz de la tarde nebulosa, brillan tristemente los remates de algunos domos y de algunas agujas caladas. He ahí, pues, a la ciudad monstruo [...]. Ahí está, severa, fría, con su frialdad protestante; poderosa y tranquila al parecer. Aún no se adivina el hormiguero humano. Algunos transeúntes, abrigados o con sus paraguas debajo del brazo, recorren de prisa las aceras, algunos cabs pasan al trote de sus grandes caballos. Eso es todo. (195-196)
\end{abstract}

Le sorprende al cronista la magnitud de una ciudad que se ha convertido en metrópolis. El observador peripatético ya no puede hacer legible la totalidad de la ciudad. Sólo las cifras -la asunción de una mirada general, panorámica- permiten representar la capital británica como 'concepto urbano'. Precisamente en las décadas previas a la redacción de esta crónica, en las últimas del siglo XIX, comienzan a confeccionarse los mapas demográficos urbanos pertenecientes a las primeras encuestas sociológicas:

\footnotetext{
Para formarse idea de Londres, acaso sea necesario recurrir a algunas cifras. [...] se calcula, que entre avenidas y calles, callejuelas, pasajes y culs-de-sac posee nueve mil vías públicas, en las que se advierte una tal plenitud, una tal actividad de vida, que no la hay mayor en parte alguna del mundo. (197)
}

La ciudad monstruo/laberinto hechiza y asombra al cronista. Sin la pretensión de hacer una observación directa exhaustiva y científica de la ciudad, inicia una flanerie, una trayectoria sin rumbo fijo por sus calles. Experimenta una sensación que define como panteísmo de las 
metrópolis (expresión que recuerda la 'santa prostitución del alma' de Baudelaire de su poema en prosa Las multitudes). Al igual que Julián del Casal, dice estar poseído por el impuro amor de las ciudades y llevar en su espíritu algo del hombre las multitudes del cuento de Poe: "con una especie de festinación enfermiza, avanzo derecho hacia las fauces del monstruo, ávido de que me mezca aquella irresistible marejada del oleaje humano. Ando, ando y cuando ya he recorrido algunas millas de aceras, voy a caer jadeante en una banca de la gran plaza de Trafalgar" (198). Es importante destacar que Nervo no se identifica con el narrador del cuento de Poe, que es un flâneur reflexivo, sino con el hombre de la multitud, que es un badaud o mirón. De hecho, el cuento de Poe tematiza un problema que se le plantea muchas veces al flâneur: cuando queda deslumbrado por la multitud y el poder de atracción del espectáculo humano, puede perder su capacidad reflexiva y convertirse en un simple espectador extasiado de los signos urbanos. El flâneur que experimenta el baño de multitudes ('la marejada del oleaje humano') y queda atraído por el espacio público se convierte en badaud si pierde sus capacidades interpretativas. Por lo demás, aparece en esta crónica la metáfora del hervidero "calles donde hierve la actividad de millones de existencias" (198), muy común en la literatura urbana, para referirse a la convivencia cotidiana entre los urbanitas.

Todos los cronistas hispanoamericanos se ocuparon de retratar el mundo de las grandes exposiciones. En Los mexicanos y el cosmopolitismo, al igual que Rubén Darío, Nervo se ocupó de elogiar, como escaparate del progreso, la vida desbordante ofrecida en la Exposición de París de 1900: "Pero París me retiene y debo quedarme. Apenas hemos delineado la Exposición, y es preciso fijar, cuando menos, l'ensemble, porque es inmensa. [...] Del caos de edificios en construcción, ha surgido ya un conjunto harmonioso" (222 y 223). En esta crónica llama flanear al consumo visual de las mercancías durante la visita a la Exposición: “yo seguiré 'flaneando' por esa curiosa ciudad cosmopolita, erizada de todas las arquitecturas, que se llama el Certamen de 1900. [...]'flaneemos' por la enorme feria" (222 y 223). Tanto se flanea en el pasaje como en los espacios, muchos más grandes, de las Exposiciones Universales.

En Por las tierras de Castilla, en la sección En Ávila, el cronista emprende una flanerie que le sirve para elaborar una representación literaria de la ciudad, interpretada en función de la imagen que tiene de Santa Teresa de Jesús. Su visita a la ciudad forma parte del turismo cultural: busca 'reconocer' un conocimiento previo adquirido en los libros. En estas circunstancias, la flanerie, el perderse en las calles sin rumbo fijo, queda al servicio del reconocimiento de sus expectativas culturales: "Nada distrae, pues, al pensamiento, de la evocación piadosa de la santa, y yo, la noche primera de mi llegada, me pierdo en el laberinto de callejuelas, camino a lo largo de las murallas, entro y salto por esas enormes puertas" (235). Este es un tipo de flanerie que también encontramos en bastantes ocasiones en Gómez Carrillo: se emprende con el objetivo de confirmar las expectativas previas del viajero.

Las marcas nimias del espacio público, indicadoras de la temporalidad urbana, interesan al flâneur. Una crónica madrileña que responde a la estética de la flanerie es Terrazas de quita y pon, dedicada a la apertura de las terrazas, con la llegada de la primavera, y a su cierre, con la entrada del invierno: "Abril trajo las terrazas, esas simpáticas terrazas de quita y pon de la calle de Alcalá, que añaden una viva y alegre nota nueva al perenne bullicio de la arteria principal de Madrid"5 (Nervo 1946:36).

Nuestros hermanos los pobres es una crónica de título irónico sobre los mendigos que un flâneur se puede encontrar en la calle: "No se puede salir de casa, ni dar un paso en 
la calle, ni detenerse en un aparador, sin que nuestros hermanos los pobres se confabulen para acosarnos, para asediarnos, para cercarnos" (57). La mirada despreciativa hacia el mendigo se aleja de la mirada empática hacia la Otredad marginal, típica de clásicos de la flanerie como Baudelaire. El cronista considera que los pobres son numerosos en las calles madrileñas “(p)or la misma razón por la que han abundado en diversas partes de México. Por ese decisivo, ese enérgico, ese invencible, ese definitivo horror al trabajo, que es ya casi 'medular' en nuestro pueblo [...] el madrileño, como el mexicano [...], protege la mendicidad callejera, prodigando sus 'perras' en las calles y en los cafés" (50). Estamos alejados de la alegorización del trapero como alter ego del intelectual que se siente marginado en la sociedad burguesa. Diferente valoración le merece al cronista la figura de un místico en medio de un bulevar parisino en la escena urbana El enlutado que reza: "Un hombre alto, muy moreno, de recio bigote entrecano, cortado a la inglesa, vestido de negro, se pasea lentamente por el bulevar, a la hora febril en que el tráfico y el movimiento vespertinos llegan a su colmo" (91). Esta es una figura que, al desafiar las burlas de la multitud, merece su más alto respeto. Aquí aparece la estetización de la Otredad urbana, con la que se identifica el intelectual en su rechazo de los valores materialistas burgueses.

\section{La flanerie en José Martí}

Publicadas en diversos periódicos, las crónicas de José Martí (1853-1895) han sido organizadas según el criterio geográfico bajo el título de Escenas norteamericanas, Escenas mexicanas y Escenas europeas ${ }^{6}$.

Las crónicas de Martí han recibido cierta atención crítica. Araya (2003: 1786-7) establece una clasificación temática de las Escenas norteamericanas (292 en total, publicadas entre 1880 y 1892) y distingue las crónicas vinculadas a acontecimientos sociales y a la vida metropolitana (inauguraciones, exposiciones, bailes), donde describe la modernidad estadounidense (113 crónicas); a la vida política (82 crónicas); a procesos sociales como son los movimientos abolicionistas, el sufragio femenino, la inmigración, el movimiento obrero o la situación de indígenas y negros (42 crónicas); a la política exterior estadounidense (31 crónicas); y al arte y la literatura (24 crónicas).

Sin dejar de estar presente en los restantes temas, la mayor parte de los casos de flanerie o callejeo urbano aparecen en textos pertenecientes a la primera categoría temática. Ramos (2003: 263-270) considera que la crítica de la modernización, el principal problema debatido por Martí, le permite especificar y justificar sus funciones sociales como periodista al interior de la nueva división del trabajo intelectual que la misma modernidad incentiva; se produce, así, la situación paradójica de ver al cronista reclamar un papel autónomo y distanciado que le permita evaluar los procesos sociales, cuando al mismo tiempo lo vemos convertido en un agente especializado, como periodista, de los procesos de especialización, racionalización, emprendidos por la modernidad.

Las crónicas de Martí también han sido investigadas por Bremer (1994:116-128), en su caso desde los conceptos de velocidad y dinamismo, típicos de la representación de la modernidad. Matzat (1994: 197-209), por su parte, ha investigado la imagen de México en las Escenas mexicanas: considera que su apreciación de los acontecimientos mexicanos está mediada por una concepción liberal del progreso. Sirkó (1975: 62-67) analiza los principales recursos estilísticos utilizados por Martí en algunas de sus crónicas europeas. Cuvardic (2009) ha investigado las crónicas sobre desastres naturales El terremoto de Charleston y Nueva York 
bajo la nieve desde la narratología y la estilística y concluye que, más de cien años después, la representación informativa de estos acontecimientos emplea los mismos procedimientos discursivos. Rotker (2005: 176-186) analiza la utilización de la retórica de lo sublime al retratar las personalidades y acontecimientos estadounidenses. El elogio de esta nación necesitaba, concomitantemente, el estilo más pertinente para ello. Gomáriz (2003: 85-94) analiza la ciudad en la poesía de Martí, aspecto poco trabajado, dado que el tema urbano se ha enfocado, más que todo, en sus crónicas. De la crónica sobre la inauguración de la Estatua de la Libertad destaca Olivio Jiménez (1975: 206-221) la intención de Martí de abarcar panorámicamente el entusiasmo colectivo de los ciudadanos ante este acontecimiento (del que participa el sentimiento exaltado del cronista, que se integra plenamente en las celebraciones), así como su objetivo de elogiar a las individualidades que hicieron posible la celebración (Bartholdi, Washington, el marqués de Lafayette). Cortés-Roca (2009: 154) aprecia el papel de testigo observador de los acontecimientos en las crónicas de Martí y lo relaciona con su proyecto ideológico latinoamericano: "observar, testimoniar, escribir y traducir una cultura ajena. [...] toma las notas necesarias para desplegar el proyecto de modernización deseada para Latinoamérica.” Julio Ramos precisa este proyecto al estudiar algunas de sus crónicas, como Coney Island o El puente de Brooklyn. Considera que ofrecen una reflexión del intelectual latinoamericano en defensa de los valores estéticos de América Latina, frente al materialismo norteamericano:

El discurso martiano genera y se nutre de un campo de 'identidad' construido mediante su oposición a los signos de una modernidad amenazante, si bien a veces deseada. [...] asume, en las Escenas, la defensa de los valores 'estéticos' y ‘culturales' de América Latina, oponiéndolos a la modernidad, 'a la crisis de la experiencia', al ‘materialismo' y al poder económico del 'ellos’ norteamericano. (Ramos 2003: 30)

Martí, en una de sus primeras crónicas escritas en Nueva York, destaca la importancia de la flanerie, sin nombrarla con este término, a la hora de interpretar a la sociedad estadounidense. En Impresiones de América (Por un español muy fresco) III, a la hora de responder a la pregunta sobre el destino de Estados Unidos, sobre su significación trascendental, responde: "El observador encuentra contestaciones elocuentes a todas estas mixtificaciones mientras va por las calles"7 (Martí 2003: 1748). Es decir, la flanerie permite conocer la esencia de una sociedad y una nación. Detalla algunas de sus observaciones: “QQué veo? Una niña de siete años va a la escuela. [...] Fui a la parte baja de la ciudad en el tren elevado" (1749). El escritor extranjero asume una actitud curiosa, y por lo tanto reflexiva, ante la sociedad que desea conocer.

Martí distingue y evalúa en diferentes crónicas entre el materialismo y la racionalidad de la cultura norteamericana y la espiritualidad de la latinoamericana, entre el Ellos y el Nosotros. Lagmanovich (2003: 1851) destaca que para el periodista que describe una realidad que no es la suya, es inevitable que su escritura tematice la diferencia, el enfrentamiento entre el aquí y el allá. Un ejemplo se encuentra en el siguiente extracto de Impresiones de América (Por un español muy fresco) I, texto escrito poco después de su llegada a Estados Unidos, donde habla de las impresiones -serie de sensaciones visuales y auditivas, sobre todo- que percibe:

Guardo mis primeras impresiones vívidamente despiertas. El tropel de Broadway; la quietud de las tardes; el carácter de los hombres; el más curioso y digno de nota de las mujeres; la vida de hotel, que nunca será comprendida por nosotros; aquella joven soñadora, más fuerte física y mentalmente que el hombre joven que la corteja; esta vida enfebrecida; este asombroso movimiento; este espléndido pueblo enfermo, de un lado maravillosamente extendido, del otro -el de los placeres intelectuales- pueril y pobre; este colosal gigante candoroso y crédulo; estas mujeres, demasiado ricamente vestidas para ser felices; estos hombres demasiado entregados a los asuntos del bolsillo, con notable olvido de los asuntos espiritualestodo viene al mismo tiempo y comienza a organizarse en este breve relato de mis impresiones. (1737) 
Muchas de estas observaciones, sujetas a una evaluación dicotómica, provienen de la experiencia de Martí en las ciudades norteamericanas. Discursivamente, se sujeta a las convenciones de la flanerie periodística decimonónica. Logra distinguir la velocidad de la vida urbana ("esta vida enfebrecida; este asombroso movimiento") y la sinfonía de la ciudad ("el tropel de Broadway; la quietud de las tardes"). Distingue, además, la racionalidad anglosajona de la espiritualidad latina ("pobres en placeres intelectuales", "entregados a los asuntos del bolsillo"). Demuestra Ramos (2003: 268) que las crónicas utilizan reflexiones sobre las culturas anglosajona y latina que más tarde serían desarrolladas desde la forma ensayística por Rodó.

Martí también utiliza metáforas usadas en el siglo XIX para caracterizar los textos fragmentarios sobre la modernidad cultural. En Impresiones de América, ya mencionada, la percepción visual del observador se expresa mediante el término impresiones (otros escritores, como Gómez Carrillo o Ambrogi, utilizan el de sensaciones). El cronista considera que sus observaciones (a pesar de la connotación de superficialidad que pudiera llegar a tener el término impresiones) se caracterizan por ofrecer una radiografía verídica y representativa del 'alma' del pueblo estadounidense.

También Martí participa en la descripción del espacio público callejero neoyorkino en Un día en Nueva York, donde incorpora la construcción de un Ellos (los anglosajones) materialista. La crónica inicia con el amanecer, que ya supone un movimiento acelerado en la sinfonía urbana:

\footnotetext{
¡Un día en Nueva York! Amanece y ya es fragor. Sacan chispas de las piedras los carros que van dejando a la puerta de cada sótano el pan y la leche. La campanilla anuncia que el repartidor ha dejado el diario en la caja de las cartas. Bajan los ferrocarriles aéreos, llamando al trabajo. Los acomodados salen de la casa [...] Los pobres van en hilera [...] Y debajo de la ciudad la vida ruge: se atropella la gente; los carros, como en las batallas épicas, se traban por las ruedas: sube por el aire seco un ruido de cascada. [...] Llega el mísero a su despacho luminoso [...] y se dispara un tiro. [...] La gente se encoge de hombros: ¡una bestia menos! Y el día sigue su curso (1124-5).
}

Es clara la intención de compendiar las actividades más representativas que la Babilonia anglosajona realiza durante un día.

Martí redactó desde Estados Unidos crónicas sobre exposiciones o ferias dedicadas a diferentes temas. Adopta el papel de espectador en La exhibición de flores, o en Gran exposición de ganado. Los bailes también forman parte de sus observaciones: De Washington. El baile de nuestro ministro, así como la botadura de un barco en Proa al mar. La salida de un vapor.

Si bien Martí no se representa a sí mismo en sus crónicas en su papel de periodista testigo de los acontecimientos, son bastantes las que nos indican su papel de observador directo de acontecimientos públicos que se describen desde el procedimiento de la escena. El periodista flâneur en plena actividad aparece en Fiesta de la Estatua de la Libertad, durante la ceremonia de la inauguración: "Allí va un hombre de mirada ansiosa, tomando apuntes a la par que anda" (761). Olivio Jiménez (1975: 204) considera este enunciado como una rúbrica anónima de la presencia misma de Martí en los festejos. Trátese de sí mismo o de otra persona (talvez otro periodista), sí podemos concluir que se trata de la figura de un observador distanciado reflexivamente que pretende representar un acontecimiento público. En todo caso, la asunción del papel del flâneur por el cronista, por el propio Martí, es más clara en la siguiente cita de Fiesta de la Estatua de la Libertad: "Sigamos, sigamos por las calles a la muchedumbre que de todas partes acude y las llena" (761). 
La representación de la ciudad a partir del callejeo aparece en algunas crónicas de las Escenas norteamericanas, escritas entre 1880 y 1890, en las que asume una posición ideológicamente crítica con el progreso norteamericano. Se resiste "a producir una imagen decorativa de la ciudad" (Ramos 2003), típica de la mirada de otro tipo de flâneur, aquel que disfruta de la ciudad como si fuera un gran almacén de novedades (más ligada, por ejemplo, con Enrique Gómez Carrillo). En algunas Escenas Norteamericanas denuncia, por ejemplo, la pobreza de las zonas urbanas marginadas.

La multitud es, en Martí, símbolo de la pujanza económica de Estados Unidos y del civismo de sus ciudadanos. En la Carta de Nueva York, fechada el 24 de diciembre de 1881, declara el cronista: “QQué multitudes!” “¡Son bosques humanos! [...] Afluyen en las calles, como ríos, procesiones de paseantes: el buhonero pregona sus baratijas" (128). En esta crónica, como en muchas otras, Martí también describe rápidamente diversos tipos humanos neoyorkinos. Asimismo, en Inauguración, antes de los actos de investidura del nuevo presidente norteamericano, Cleveland, describe y evalúa a los espectadores ('el público es el espectáculo', procedimiento típico de la flanerie que encontramos también en Gutiérrez Nájera, Gómez Carrillo, etc.): "Doscientos mil forasteros han llegado a Washington para las ceremonias de la inauguración" (1188); "Los trenes llegan, con una bandera en cada ventanilla, con su carga de californianos..." (1188); "Ya a las ocho era Washington como una masa viva. [...] la muchedumbre, con el agua corriéndole por el cuello, invade los peldaños en la avenida, vaga alrededor de los estrados vacíos" (1189). La pobreza, para remarcar la otra cara del progreso y la democracia, también recibe atención en esta última crónica: "Allá afuera, por entre líos de negros, acurrucados en los quicios, halla el cuerpo la procesión de los míseros, como los paraguas inútiles a rastras" (1188).

Una crónica que adopta la perspectiva enunciativa del flâneur, y a la vez una de las más conocidas de Martí, es Fiesta de la Estatua de la Libertad. Tras el panegírico que Martí lanza hacia la libertad como valor democrático, podemos identificar en su crónica sobre la inauguración de la Estatua el punto de vista de un intelectual que anhela fervorosamente la independencia cubana.

Desde la perspectiva del testigo observador, la mayor parte de la crónica se dedica a describir el protocolo del acto de inauguración de la estatua: los discursos de los políticos y del escultor; los desfiles de los soldados; el momento culminante de la develación de la estatua, la multitud... Inmerso en la multitud, Martí, en su condición de emigrante, presta mucha atención a la alegría que tiene el pueblo norteamericano por vivir en libertad, descrita con todo detalle: "los hombres pasmados de su pequeñez, se miraban al pie del pedestal, como si hubieran caído de su propia altura: el cañón a lo lejos retemblaba: en el humo los mástiles se perdían: el grito, fortalecido, cubría el aire: la estatua, allá en las nubes, aparecía como una madre inmensa" (762). Martí abandona el papel de testigo afectivamente distanciado y se integra en la alegría de la celebración, actitud poco común en sus crónicas.

Asume el punto de vista del observador presencial El puente de Brooklyn, dedicada a la inauguración de esta vía de comunicación, uno de los símbolos de la modernidad tecnológica en Estados Unidos a finales del siglo XIX. Ramos (2003: 210), además de identificar procedimientos de estilización añadidos al discurso referencial tecnológico (la descripción del puente, que ocupa la mayor parte del texto), logra ver la importancia de la retórica del paseo, sobre todo al quedar enmarcada la narración con elementos de la guía turística y al utilizar mecanismos como la incorporación del lector en las observaciones del cronista. Cortés- 
Rocca (2009: 154) se equivoca cuando señala que la mirada del enunciador en esta crónica no corresponde a la del flâneur (como propone Ramos), al considerar que no es un paseo azaroso, sino la del cronista asalariado. Olvida que ya desde la década de 1830 se asocia la flanerie con la práctica periodística (desde Balzac). El procedimiento enunciativo conocido como nosotros inclusivo, permite incorporar al lector como testigo virtual que se hará una imagen mental de este último acontecimiento: "De la mano tomamos a los lectores de La América, y los traemos a ver de cerca [...] este puente colgante" (269). También guía al lector en el momento de pagar el pasaje y entrar al puente: "Llamemos a las puertas de la estación de New York. Millares de hombres, agolpados a la puerta central nos impiden el paso" (270). Los ojos del cronista, como flâneur, se concentran en numerosas ocasiones en la multitud, entidad compuesta más que todo por emigrantes. Ramos (2003: 210) explica el uso de este procedimiento: "La crónica martiana escenifica los mecanismos productores de la ilusión de presencia. Presupone, en ese sentido, las convenciones del discurso referencial. [...] La referencia se autoriza en la retórica de la transparencia del discurso y en la presencia del sujeto que 've' lo que cuenta." Es decir, la funcionalidad persuasiva del flâneur es persuadir al lector latinoamericano de la referencialidad del texto. La interpelación al lector latinoamericano, utilizada durante la descripción de una obra humana caracterizada por la sublimidad, también es empleada constantemente en Fiesta de la Estatua de la Libertad.

El cronista realiza una descripción del puente en términos de 'maravilla' de la ingeniería, con el objetivo de demostrar la magnitud que ha alcanzado el progreso estadounidense: "Levanten con los ojos los lectores de La América las grandes fábricas de amarre que rematan el puente de un lado a otro" (272). Martí describe en numerosas crónicas sobre la pujanza del desarrollo industrial y tecnológico estadounidense ${ }^{8}$.

La fuerza del progreso encuentra un símbolo representativo en el ferrocarril elevado de Nueva York y su valor paradigmático, la velocidad. La crónica Ferrocarriles elevados representa esta experiencia: "Y vuela el tren, escupiendo y retemblando: a tragos enormes se sorbe las calles: siete pisos tiene esa casa que no llega con el tope al borde de los rieles; ya las estaciones no están a pocas varas de la calle, ni son torres verdaderas" (1046).

Frente a la pujanza económica de Estados Unidos, Martí también destaca su contrapartida, la miseria, como sucede en Por la bahía de Nueva York. Describe cómo transcurre el verano para los pobres de Nueva York. Justifica la descripción de la miseria apelando al sentido de empatía; el ser humano se degrada "cuando no templa de vez en cuando el amor exclusivo a su bienestar con el espectáculo de la desdicha ajena” (1085). Describe cómo los obreros exhaustos procuran combatir el calor en los tejados de los edificios, mientras los niños se tienden de bruces en las baldosas y las madres exangües se ubican al pie de un árbol o en los peldaños de una escalinata; por último, se detiene a describir una excursión de niños pobres a la orilla del mar, patrocinada por organizaciones caritativas. En Impresiones de América (Por un español muy fresco) III, el sufrimiento de la miseria también acapara la atención del cronista, desde la empatía, durante un paseo nocturno:

Los placeres de las ciudades comienzan para mí cuando los motivos que les producen placer a los demás se van desvaneciendo. El verdadero día para mi alma amanece en medio de la noche. Mientras hacía anoche mi paseo nocturno usual muchas escenas lastimosas me causaron impresión penosa. Un anciano [...] se pasea silenciosamente debajo de un árbol callejero. Sus ojos, fijos sobre las personas que pasaban, estaban cuajados de lágrimas [...] Una pobre mujer estaba arrodillada sobre la acera [...] Pasé por Madison Square, y vi a cien hombres robustos padeciendo evidentemente las angustias de la miseria. (1750) 
Por su parte, Coney Island es una crónica dedicada a describir el ímpetu de este lugar como principal centro de veraneo de los estadounidenses. Martí utiliza sus clásicas reflexiones sobre la cultura norteamericana y, por contraposición, sobre la latinoamericana. Ramos (2003: 255-7) considera que esta crónica es una de las primeras críticas latinoamericanas a la industria cultural; Martí operaría con un concepto de cultura como defensa de los valores espirituales, frente a los mercantiles, como crítico defensor de la alta cultura ${ }^{9}$. Creo, por el contrario, que Martí desarrolla un movimiento pendular de atracción y rechazo hacia las modalidades de ocio del pueblo estadounidense. Muestra de la primera actitud es el siguiente extracto, que oculta la actitud personal del enunciador: "lo que asombra allí, el tamaño, la cantidad, el resultado súbito de la actividad humana, esa inmensa válvula de placer abierta un pueblo inmenso [...] ese vertimiento diario de un pueblo portentoso en una playa portentosa; esa movilidad, ese don de avance, ese acometimiento, ese cambio de forma, esa febril rivalidad de la riqueza" (84). En el pensador cubano se presenta esa dialéctica, común en diversas crónicas, entre el elogio de la pujanza económica de un pueblo emprendedor y, al mismo tiempo, la crítica de su excesivo utilitarismo y la denuncia de la miseria y de la soledad. Consideremos un caso de movimiento dialéctico. En Coney Island, el cronista primero se ocupa de los visitantes latinoamericanos a este centro de ocio, "que por mucho que las primeras impresiones hayan halagado sus sentidos, enamorado sus ojos, deslumbrado y ofuscado su razón, la angustia de la soledad los posee al fin, la nostalgia de un mundo espiritual superior los invade y aflige" (84). Inmediatamente deja atrás estas reflexiones y pasa a describir su asombro ante la industria del ocio: "Pero, ¡qué ir y venir! ¡qué correr del dinero! ¡qué facilidades para todo goce! ¡qué absoluta ausencia de toda tristeza o pobreza visibles!" (84-5). Y si bien prosigue la descripción elogiosa de este lugar - "Mas no hay en ciudad alguna panorama más espléndido que el de aquella playa de Cable, en las horas de la noche" (85), se desprende del final de la crónica una evaluación crítica de este espacio como lugar espiritualmente vacuo que no logra hacer olvidar al neoyorkino su espacio complementario, la ciudad que, con la maquinaria implacable del trabajo, le terminará por devorar: "hasta que llegadas ya las horas de la vuelta, como monstruo que vaciase toda su entraña en las fauces hambrientas de otro monstruo, aquella muchedumbre colosal, estrujada y compacta se agolpa a las entradas de los trenes que repletos de ella, gimen, como cansados de su peso, en su carrera por la soledad que van salvando" (86). Los problemas sociales son planteados con regularidad por Martí. Rodríguez (2003) destaca que las luchas entre capitalistas y obreros, y particularmente las huelgas, ocuparon a Martí en diversas crónicas. Es el caso, por ejemplo, de La revolución del trabajo, crónica que concluye con la escena de una huelga.

Una escena descrita desde el distanciamiento del flâneur, en su función de testigo, es Un funeral chino: los chinos en Nueva York. Los inmigrantes acaparan la atención de Martí en diversas ocasiones. El cronista describe como observador el funeral, actitud que incluso expone al inicio del texto: "Hoy hay música extraña, la música de los funerales de Li In Du. Vamos, con Nueva York curiosa, a oírla" (1141). El vamos se refiere a un nosotros occidental que se acerca al Otro oriental con curiosidad, con 'sed' de conocimiento. Morán (2005: 399-406) ha analizado esta crónica desde el orientalismo e identifica dos imágenes de China: la heroica que lucha contra el imperialismo (al describir los funerales del general Li In Du) y la moralmente depravada (en la descripción racista, de orientación taxonómica, de los chinos de la calle Mott). Otras crónicas que asumen el punto de vista del observador en espacios públicos, en las que no 
es necesario detenerse, son Un gran baile en Nueva York, Cómo se crea un pueblo nuevo en los Estados Unidos, o ¡Magnífico espectáculo!, sobre el circo de Bufalo Bill.

Cabe destacar, por último, que son numerosas las crónicas urbanas donde se mencionan rápidamente los tipos sociales de los espacios públicos estadounidenses, principalmente de los neoyorkinos. Por poner un solo ejemplo, en El puente de Brooklyn, el cronista singulariza, entre la multitud, a hebreos, irlandeses, escoceses, rusos, noruegos, japoneses, chinos, policías, mozos, damas (269-270). La intención de Martí es perfilar los tipos sociales característicos de este país, incluidos los inmigrantes.

\section{La flanerie en las crónicas y cuentos de Manuel Gutiérrez Nájera}

La escritura de Gutiérrez Nájera representa, según Sirkó (1975: 60) "la veta francesa o parisiense del modernismo", afirmación que también ha sido planteada al hablar de Gómez Carrillo. Sobresalen las crónicas de temas morales Cuaresmas del Duque Job, así como 56 crónicas dominicales publicadas en El Universal del 3 de diciembre de 1893 al 6 de enero de 1895. Son conocidos sus pseudónimos, herencia del periodismo costumbrista: Puck, Monsieur Can-Can, Recamier y, sobre todo, El Duque Job.

En ocasiones Gutiérrez Nájera reescribió sus crónicas, publicadas en periódicos ${ }^{10}$, para convertirlas en cuentos. Avilés (2006: 114) analiza los procedimientos utilizados en esta reescritura: eliminación de algunas marcas referenciales (fechas precisas, nombres de personas reales, acontecimientos relevantes de la época), sustitución de palabras de uso cotidiano por un léxico más estilizado, empleo de la adjetivación y, por último, utilización de un contrato de lectura diferente, que distingue entre información y entretenimiento. Pero en términos estrictamente enunciativos y referenciales (en el marco de la representación de la ciudad), tanto las escenas de los cuentos como las procedentes de las crónicas emplean los mismos procedimientos discursivos. En este sentido, al identificar la flanerie en la escritura de Gutiérrez Nájera, utilizaremos ejemplos procedentes de estos dos géneros.

Lo más típico en las crónicas urbanas del escritor mexicano es el elogio de la modernidad social, cultural y económica, fundamentada en el desarrollo del comercio, la promoción de la higiene (tanto en términos sanitarios como morales), los medios de transporte, los medios de comunicación, la luz eléctrica y la creación de bulevares. Complementariamente se presenta la domesticación, omisión o rechazo de la Otredad urbana, como también sucede con Casal y Gómez Carrillo. Ramos (2003: 168) sintetiza esta actitud, a la que define desde la metáfora de la vitrina:

Incómodo entre la muchedumbre [...] el sujeto privado sale a objetivar, a reificar el movimiento urbano mediante una mirada que transforma la ciudad en un objeto contenido tras el vidrio del escaparate. La vitrina [es ][...] una metáfora de la crónica misma como mediación entre el sujeto privado y la ciudad. La vitrina es una figura de la distancia entre ese sujeto y la heterogeneidad urbana que la mirada busca dominar, conteniendo la ciudad tras el vidrio de la imagen y transformándola en objeto de su consumo.

La crónica El Progreso y el teatro es paradigmática del elogio de la modernidad. Se elogia una modernidad importada, definida más que todo a partir del espacio público:

\footnotetext{
Parece que ha sonado para nosotros la palabra mágica, y que vamos entrando a uno de esos países fabulosos que describen los narradores orientales. Comienzan a cumplirse las profecías: se construyen ferrocarriles; se establecen bancos; llegan colonos más o menos italianos; se ven patillas rubias, fisonomías rubicundas y zapatos de tres kilómetros [...]. Es necesario que entremos en el movimiento, so pena de ser aplastados
} 
por la locomotora. Hablando en serio, jamás se había encontrado México en una situación tan próspera como la presente. [...] Las calles van siendo estrechas para la circulación holgada de los transeúntes; los grandes focos de luz eléctrica nos permiten soñar con las maravillas de París (Peña y Maiz 1988: 45).

El principal valor que se desprende de este tipo de evaluaciones es la velocidad del cambio social, del progreso.

En sintonía con los presupuestos ideológicos burgueses de este cronista, Puestas de Sol nos ofrece las apreciaciones de un flâneur impresionista maravillado por los atardeceres en la ciudad de México. Interpela a sus lectores, burgueses que tienen tiempo libre, para que emprendan la misma actividad: "Pasead a esas horas por la Calzada de la Reforma, si no podéis alejaros más de la ciudad. ¿No habéis observado cómo las ciudades marchan rumbo a Occidente?"11 (Gutiérrez 1940: 84-5). Esta pregunta retórica supone el inicio de la segunda parte de la crónica, dedicada a elogiar la modernidad cultural de la sección occidental de la capital mexicana y a repudiar el tradicionalismo en el que vive la sección oriental, anclada en la Colonia. Termina con un panegírico de la Calzada de la Reforma, recorrida por diplomáticos, amazonas, comerciantes extranjeros o nobles perros de casas ricas: "Por las tardes, esa pequeña faja trazada por el café de Zepeda, parece como desprendida de parisiense boulevard." (87). Este texto no es sino el elogio de un estilo de vida chic, aquel que disfrutan los lectores que leen su crónica. Es la misma modernidad que retrató en Manet en cuadros como El concierto en las Tullerías.

Gutiérrez Nájera asume claramente una mirada burguesa sobre la sociedad mexicana de su tiempo. Hasta tal punto es así, que siente la necesidad de excusarse ante su público lector, en la crónica Los toros de noche, por asistir al espectáculo de una corrida nocturna: "Tendré la franqueza de confesarlo: fui a los toros. ¡Ya he escrito estas palabras y no las retiro! No quiero pasar por hipócrita: con insolencia, con absoluta desvergüenza, lo confieso: ¡fui a los toros!” (89). Recordemos la actitud del enunciador en la crónica de Casal, El circo oriental, donde se disculpa ante los lectores por negarse a describir la función, repelido por la muchedumbre y la sociedad. Transcribimos la llegada al espectáculo en la crónica de Gutiérrez Nájera:

\footnotetext{
El verdadero cuadro pintoresco, más que en la plaza, estaba en la Avenida de la Reforma. Como invasión de grandes luciérnagas, brillaban los faroles de innumerables coches, convirtiendo por un momento la calzada en bullicioso boulevard, pero boulevard sin casas, sin cafés y oscuro. Las lumbreras y los tendidos de la plaza rebosaban de gente. La parte del sol -el sol nocturno, el sol de Justo Sierra-, parecía cubierta por una ola humana. De esa ola salían clamores de océano, cinco mil gritos que se magullaban en el aire. (92)
}

El anterior extracto nos presenta algo típico de las escenas descritas por el flâneur, ya sea costumbrista o modernista: no se describe el espectáculo en sí, sino a los espectadores y al ambiente que los rodea. Recordemos, por ejemplo, que ya el ocioso del teatro [theatrical Idler] en La historia natural del ocioso urbano (1848), de Albert Smith, se dedicaba a observar al público espectador, al igual que Mesonero Romanos, en el artículo El teatro por fuera, y Gómez Carrillo en su visita al Teatro Colón en la crónica En los grandes teatros, del volumen El encanto de Buenos Aires. La crónica de Gutiérrez Nájera también nos indica que, ocasionalmente, la escritura tipificada por lo general como modernista no sólo asume las convenciones descriptivas de la escena costumbrista, sino que también se apropia de su terminología ("cuadro pintoresco", define la voz enunciativa a la escena). Por otra parte, el alumbrado público (típico tanto en artículos costumbristas como en crónicas modernistas), 'domestica' el espacio nocturno, le impone un orden, lo hace legible, lo convierte en un 'interior' seguro. Por lo demás, la metáfora marítima (ola, océano), clásica en la descripción de la multitud, también se emplea. Antes de 
describir la corrida, la corriente eléctrica se va y deja la plaza a oscuras, hasta que unos focos eliminan parcialmente la oscuridad imperante. En tono jocoso se describen las dificultades que tienen que los espectadores para distinguir la lidia. Esta crónica se puede comparar con Madrid a la luna, de Mesonero Romanos, con Streets-Night, de Sketches by Boz, de Dickens y, sobre todo, con Eclipse total, de José Milla, artículo centrado en las dificultades que tienen los transeúntes de la capital guatemalteca cuando se apaga el alumbrado público.

Como en otros textos de Gutiérrez Nájera, también el enunciador del cuento Stora y las medias parisienses utiliza el encuadre de la ciudad organismo para retratar a la ciudad de México como espacio en descomposición: "Las primeras lluvias han convertido la ciudad en un mar fétido, donde se hospedan las amarillas tercianas y el rapado tifo" (135). El cronista centra su discurso en la suciedad, con lo que exhibe la actitud burguesa que asocia la higiene física con la moral ${ }^{12}$.

Otro tema tratado por Gutiérrez Nájera es la Navidad (presente también por Casal y por Martí). Un caso lo ofrece La Noche Buena en México. Destaca la descripción de una procesión y de sus participantes, así como de los fuegos artificiales y de las tiendas navideñas. Observar la festividad motiva al cronista a recordar, con nostalgia, las tardes de su infancia: "¡Cohetes que anunciáis la Noche Buena, cuántos recuerdos traéis a mi memoria! [...] Yo he recorrido, pensando en esas alegrías, las tiendas y barracas en que se venden objetos para el Nacimiento" (81). Más centrado en los comercios es el cuento Las misas de navidad, donde el periodista flâneur observa las barracas de la Plaza Principal. Recordemos que la descripción de los mercados aparece tanto en las escenas costumbristas como en las crónicas modernistas. En estas ocasiones, el flâneur observa a otros transeúntes durante el acto de compra. También ocurre en el cuento de Gutiérrez Nájera, donde, además de destacar el empleo de la palabra flanear, se aprecia su despectiva visión aristocrática hacia la multitud: "He salido a flanear un rato por las calles [...] Las barracas esparcidas miserablemente en la Plaza Principal han estado esta tarde más animadas que nunca. [...] A trechos, rompiendo la monotonía de aquella masa humana vestida de guiñapos, asoma una coraza aristocrática y un sombrero a la Devonshire" (Gutiérrez 1983: 487) ${ }^{13}$. La descripción se concentra en la atención que prestan los transeúntes hacia las mercancías navideñas ofrecidas: "Igual animación reina en las calles [...] Apenas es posible transitar por las aceras [...] Junto al cristal de cada aparador se agrupan los curiosos transeúntes, y observan con fijeza, ya las velas microscópicas de esperma, que han agotado todos los colores del iris, ya los juguetes caprichosos y droláticos, ya las cajas y obsequios de año nuevo" (488). En este cuento se utiliza el procedimiento descriptivo de la escena, e incluso se menciona el término 'animado', muy utilizado en el costumbrismo español (en el británico se utiliza el término equivalente amusement).

Una de las más claras afiliaciones que los narradores de los cuentos de Nájera manifiestan con la actividad de la flanerie aparece en La cucaracha, que describe un callejeo nocturno. Como sucede en este tipo de escenas, la mirada no sólo se focaliza sobre el sistema iluminación utilizado en las calles, sino también sobre los tipos sociales paradigmáticos que transitan durante estas horas:

\footnotetext{
El caso es que ayer noche erraba meditabundo por las calles, cuyo aspecto, cuando la luz eléctrica se apaga, es el de un ataúd negro y sin capa. Sin objeto determinado, ni prefijo derrotero, iba a merced de mi capricho, pensando en muchas cosas que han pasado y en otras que todavía no han sucedido: esto es visión, pero no en el presente ni en el medio. [...] A tales horas no se encuentra en las calles ánima viviente, a no ser el gendarme que ronca en el portal de alguna tienda o el cochero que va dormido en el pescante, dejando a las flacas mulas el cuidado de conducirle a la carrocería. (385)
} 
Cuando el narrador afirma que "ayer noche erraba meditabundo por las calles" y que "sin objeto determinado, ni prefijo derrotero, iba a merced de mi capricho", se identifica claramente como flâneur: errante en el trayecto físico de la ciudad y errante en su pensamiento.

En la calle (reelaboración de las crónicas En las carreras y Crónicas de las carreras) es un cuento donde el protagonista callejea por barrios no familiares tanto para el paseante burgués como para el pequeño burgués: "Yo, que transito poco o nada por aquellos barrios, fijaba la mirada con curiosidad en cada uno de los accidentes y detalles... Distraído fijé los ojos en el balcón de la casita que he pintado" (185-186). Cerca del balcón se encuentra una mujer tísica. La cita precedente tipifica muy bien la actividad del callejeo. En primer lugar, el tránsito por espacios desconocidos sin rumbo fijo ("yo, que transito poco o nada por aquellos barrios"); en segundo lugar, la actitud curiosa ante la realidad urbana ("fijaba la mirada con curiosidad en cada uno de los accidentes y detalles..."). Puede compararse la situación descrita en esta escena con la ofrecida por diversos cuadros de las pintoras impresionistas (Berthe Morisot, Mary Cassatt) donde, desde una mirada situada en el interior hogareño, aparecen personajes femeninos recluidos que observan el espacio público con anhelo o nostalgia. Este cuento de Gutiérrez Nájera también guarda una relación directa con Croquis femenino (Fragmentos), de Casal, donde el flâneur, en su callejeo, reconoce en una ventana a una mujer cuya dudosa reputación le ha obligado, finalmente, a retirarse en el refugio hogareño.

En el cuento En la calle, con ocasión del paso de unos carruajes ocupados por damas, el enunciador percibe fragmentos de realidad, sinécdoques, shocks visuales, acontecimientos fugitivos que intenta fijar: "Esto es: vida que pasa, se arremolina, bulle, hierve; bocas que sonríen, ojos que besan con la mirada, plumas, sedas, encajes blancos y pestañas negras” (186. La cursiva es añadida). Destaca la utilización de la metáfora bullir, hervir, típica de muchos textos urbanos del siglo XIX que describen la actividad callejera. La estética del shock visual, que posteriormente será típica de las vanguardias, queda prefigurada en representaciones urbanas previas, como es el caso de la crónica modernista. Lo más representativo de la ciudad queda retratado por medio de sinécdoques: ruidos y voces, bocas, ojos, vestidos lujosos (plumas, sedas, encajes), maquillaje (pestañas negras). Gutiérrez Nájera no se ocupa del espectáculo de las cosas (con excepción de algún cuento que sitúa en un comercio, como en Historia de un paraguas), sino del espectáculo de la vida, desde una ideología que otorga una valencia positiva al progreso industrial y urbano, tal como se manifiesta en las prácticas públicas de la sociabilidad burguesa (paseos en parques, transeúntes en avenidas), como contrapartida a la ideología de las ciudades muertas, propias de la tendencia decadentista de la estética fin de siglo, que implícitamente otorga una valencia negativa al progreso.

Otro cuento que describe la actividad visual y auditiva del flâneur es Una cita, que Jofre (2002: 131) y Ramos (2003: 172) asocian con acierto a la actitud del voyeur. El enunciador confiesa al inicio del cuento: "Acostumbro en las mañanas pasearme por las calzadas de los alrededores y por el bosque de Chaputepec. El sitio predilecto de los enamorados./ Esto me ha proporcionado ser testigo involuntario de más de una cita amorosa" (361). En su actitud voyeur, llega a conocer una historia:

Algunas frases llegaron a mi oído: no eran dos enamorados: eran madre e hijo. Sin quererlo supe toda una historia, una verdadera novela que se interesó extraordinariamente, que me hizo ser no sólo indiscreto, sino desleal, porque venciendo mi curiosidad a mis escrúpulos me hizo acercar más y más a la pareja que abstraída en la relación de sus desdichas, no me apercibía, no oía mis pisadas sobre las hojas secas de los árboles derramadas por el suelo. (361) 
El flâneur, cuando desarrolla una mirada voyeurista y escucha conversaciones ajenas, invade el espacio íntimo de los transeúntes y paseantes. De la misma manera que las relaciones anónimas en las metrópolis se caracterizan por la mutua reserva, como ya señaló Georg Simmel, también se desarrolla en el urbanita, en este caso en el flâneur, la necesidad de recuperar la comunicación empática con sus conciudadanos mediante tácticas como el voyeurismo.

Los nacientes grandes almacenes comienzan a quedar representados en la literatura occidental en la segunda mitad del siglo XIX (en Casal aparece en la crónica sobre El Fénix). Esta modernidad se representa en Memorias de un paraguas, donde este objeto, dotado de pensamiento, describe con todo 'lujo' de detalles este espacio de consumo: el carácter suntuario de los objetos queda descrito desde el lujo escritural (se emplea el recurso de la acumulación) ${ }^{14}$. Una vez que un cliente compra el paraguas, este objeto es víctima del caos callejero, que describe desde la estética de la velocidad, de las impresiones visuales, de la acumulación descriptiva, típica de la estética de la urbe. Si bien este objeto no es un flâneur extranjero o pueblerino que se asombre del bullicio urbano, comparte, en todo caso, la perspectiva reflexiva, distanciada, de esta última figura urbana. Su dueño visita una peluquería y asiste al teatro. Esta es una ocasión para realizar una crítica teatral: "No hay remedio. He caído en una ciudad que se fastidia y voy a aburrirme soberanamente. No hay remedio" (247). Otra vez en la calle, como un transeúnte más, maltratado por su dueño y anhelante de la comodidad del hogar, hecha de menos su vida en el interior comercial: "No tardé mucho en recibir nuevos descalabros, ni en sentir, por primera vez, la humedad de la lluvia. Los paraguas no vemos el cielo sino cubierto y oscurecido por las nubes [...] Eché de menos la antigua monotonía de mi existencia; la calma de los baúles y anaqueles; el bullicio de la tienda y el abrigo caliente de mi funda" (247). La flanerie del dueño y del paraguas prosigue. Este último narra el movimiento de una estación de ferrocarril e individualiza tipos sociales entre la multitud de viajeros, sobre todo parejas de enamorados (249-50). De nuevo, como en otros cuentos y crónicas, la multitud es objeto de rechazo. Salvador Jofre (2002: 126) considera que en algunas crónicas de Gutiérrez Nájera los enunciadores comprenden la ciudad desde la metáfora de la selva. Precisamente una de las metáforas maestras para comprender la ciudad en los dos últimos siglos ha sido la ciudadjungla (Langer 1984). Considero que en Gutiérrez Nájera conviven la ciudad selva y la ciudad organismo: más allá de los espacios seguros para el burgués (parques, bulevares), la ciudad es, sobre todo, un espacio caótico en descomposición ${ }^{15}$.

\section{La flanerie en Arturo Ambrogi}

Es poco conocido como cronista el salvadoreño Arturo Ambrogi (1874-1936), quien fundó y dirigió, entre 1894 y 1895, la revista semanal El fígaro. Sus crónicas se encuentran recopiladas en libros como Sensaciones del Japón y de la China (1915), Crónicas marchitas (1916) o El libro del trópico (1918). Utiliza el término 'sensaciones' en sus crónicas sobre culturas extranjeras, que Gómez Carrillo emplea en esa misma época. En la primera parte, El Japón pintoresco, de Sensaciones del Japón y de la China (1915), ocasionalmente emplea la flanerie como procedimiento que le permite observar y describir la cultura oriental. Ocurre, por ejemplo, en el capítulo La fiesta de las linternas: "Las calles de Tokio son una calamidad: sobre todo las centrales. Desfilo frente a los feudales muros" (Ambrogi 1963b: 22) ${ }^{16}$. La visita al Palacio Imperial provoca en el cronista dos sentimientos que ya han sido identificados en las crónicas de Gómez Carrillo (Cuvardic, en prensa). Nos referimos al desprecio por la 
experiencia del turismo masivo, que mercantiliza y occidentaliza a Occidente, y el desengaño, el incumplimiento de las expectativas culturales, hacia los lugares visitados de la cultura oriental, invadida por una irrefrenable occidentalización:

\begin{abstract}
Hemos llegado al Imperial. Mi ensueño japonés se borra [...]. En el «hall» espacioso [...] están los ingleses, están los yanquis, están los alemanes; la raza de antipáticos turistas que lo infestan todo, que ponen su mancha en el esplendor de todo paisaje. Voy a ellos. No hay remedio. Y sentado cerca de uno de los veladores de mimbre (¡importados de Europa!) tomo una de las tantas ilustraciones extranjeras que por ahí ruedan, y me pongo a hojearla, melancólicamente. (23)
\end{abstract}

Como sucede con los cronistas del modernismo, Ambrogi experimenta un movimiento dialéctico entre la actitud de adoptar el papel del turista y el de repudiarlo. Se asoma a la ventana de su hotel, en el capítulo Es togo que pasa..., pero inmediatamente sufre la decepción de las expectativas frustradas: "Tokio amanece envuelto en andrajos, pringoso, antipático, en lugar de ofrecernos la mañanita que esperábamos, fresca, clara" (33-34). Este es el momento en el que constata hasta qué punto el Japón de las estampas, "el Japón, falsificado por Pierre Loti y divinizado por Lafcadio Hearn, está contaminado de occidentalismo, y hasta dónde es cierto que agoniza, que se va, sin remedio. El Japón se europeiza... pero sin dejar de ser el Japón" (34-5). Por lo demás, en las crónicas de este volumen predomina la mirada del flâneur de los bulevares, típica también en los numerosos volúmenes de Gómez Carrillo. En Las tiendas de Ginza se describe esta calle de Tokio, verdadero bulevar japonés, "adonde afluye todo el movimiento de la enorme ciudad. Sus almacenes resplandecen de luces. Sus escaparates están arreglados con verdadero arte" (81). Impera la estética impresionista, la atracción hacia la modernidad de las superficies reflectantes, las luces, los escaparates...

La segunda parte de Sensaciones del Japón y de la China, titulada Bajo el cielo de la China, abunda en escenas callejeras que conducen a la misma evidencia, ya obtenida por el cronista en Japón: la occidentalización de China. Al pisar el Bund, en Shangai, todo le recuerda al Market Street de San Francisco: "El mismo ensordecedor movimiento de «trams» eléctricos; la misma nube de autos apestantes, y de motociclos detonantes como petardos; [...] Al igual que en Market, la muchedumbre afanosa, zumbante como una colmena [...] el mismo vendedor de diarios [...] los mismos vendedores de tarjetas postales, los mismos puestos de flores" (109-110). El cronista realiza una flanerie en rickshaw. En otra ocasión, se interna en la ciudad china con un guía, donde su actitud distanciada de turista que flanea choca contra los transeúntes atareados: "Y el corretear por las callejuelas, principia. Vamos de una a otra. Yo lo observo todo, cuando la avalancha que pasa me da lugar, frente a una tienda" (121). Se aprecia la misma actitud negativa hacia la muchedumbre ya analizada en Gutiérrez Nájera.

Ambrogi también tiene numerosas y excelentes muestras de la estética de la flanerie situada en ciudades salvadoreñas. Es el caso de Los momentos de 'San Salvador'. La mañana, incorporada a Páginas escogidas. Tematiza su actividad: "El callejeo no presenta grandes atractivos. [...] Vamos calle arriba o calle abajo, como prefiráis, lector" (Ambrogi 1958b: 76-77) ${ }^{17}$. Cada transeúnte capta el interés del cronista: una criada que sale a buscar leche, un chiquillo que va camino al mercado con un "macho" cargado de carnes, un mozo con un carretón lleno de marquetas de hielo, un afilador, un coche, una verdulera, un lechero... Los últimos párrafos describen la actividad del Mercado: en sus alrededores "bulle la muchedumbre como en una colmena las abejas. Por esas cuatro calles, el tránsito es difícil. El tranvía, va repicando su campanilla, pidiendo paso; mientras las carretas y carretones, encaraman sus ruedas sobre las aceras, o se detienen, como atascadas por la ola humana" (79-80). Los procedimientos descriptivos 
de sus escenas, como podemos comprobar, son similares a los empleados por el resto de cronistas del modernismo. La última crónica mencionada también es relevante para nuestra investigación, ya que el cronista define su callejeo al final del texto como flanerie: “ $¡ A$ casa! El café espera. Basta por ahora de flanerie" (81). No es la única ocasión en la que utiliza el término francés para referirse al callejeo o al callejero. En la crónica Alfonso Daudet en los Campos Elíseos, de Crónicas marchitas, tipifica con esta palabra su callejeo: "Y siguiendo el mismo tranquilo andar de flâneur, he llegado hasta..." (Ambrogi 1958a: 54) ${ }^{18}$.

Una crónica muy parecida a Los momentos de 'San Salvador'. La mañana es El despertar de la ciudad, de El libro del trópico, que incluso desarrolla más que la primera la estética de la flanerie. Por una parte, menciona constantemente su actividad de espectador móvil: "He salido de casa, y voy, solo, caminando al acaso. Tomo esta calle, y sigo recto, recto"19 (Ambrogi 1955a: 365); "Camino, siempre calle arriba. Voy respirando [...] la frescura matinal. Paso frente a un Parque. [...] Prosigo" (366); "Me detengo en la esquina del Parque" (367); "Veo pasar un carretón" (388). Por otra parte, aunque se detiene en la descripción de algunos de los objetos y tipos sociales callejeros, su mención es concisa, en homología expresiva con la multitud de percepciones rápidas y fragmentarias que el flâneur recibe: "La calle está sola. Nadie transita aún por ella" (365); "Una ventana se abre aquí. [...] Pasa un repartidor de pan [...] Pasa el panadero [...] Prosigo. Algunas tiendas se abren. Chirrían los tableros de los escaparates, al ser corridos" (366); "En esos momentos pasa un auto [...] Por la esquina del Fénix, el tranvía del Hospital se arrastra" (367); "En el portón de la Escuela Militar, tres oficiales conversan [...] Pasa una mujer abrumada bajo el peso de una gran canasta de verduras. [...] Todo el conjunto de la canasta es una deliciosa mancha de jugosos tonos" (368). Finalmente, comparte su aburrimiento en el Parque Dueñas con el que parece ofrecerle la imagen don José Manuel Rodríguez, situada en un medallón en el monumento de la Independencia. No es la única ocasión donde el cronista se relaciona con una imagen desde el pensamiento 'animista'. Ocurre lo mismo Ante el monumento a Verlaine, de Crónicas marchitas, ya que en la sonrisa de la estatua del poeta francés le parece percibir "una tenue melancolía" (86).

Ambrogi también cuenta con otras crónicas que asumen la mirada clásica del flâneur. Es el caso de Los ruidos de San Salvador, incorporada a Muestrarios. Está estructurada en dos partes. Analiza los cambios en la modernidad social y cultural de la capital salvadoreña a partir del símbolo del ruido. Antes, dominaba la calle el golpear de los cascos de los machos de los lecheros o el traqueteo de las carretas. Ahora, dice el narrador, domina el ruido de los medios de transporte y de los pregoneros. Queda insinuada una de las consecuencias psicológicas más importantes de la modernidad, la distracción, provocada por el exceso de ruido, por la excitación demasiado elevada de los sentidos. El ciudadano "(p)asa el día entero con la misma musiquita aturdiéndole los oídos, quitándole la atención para realizar cualquier acto que la requiera" (Ambrogi 1955b: 40) ${ }^{20}$.

A veces la flanerie se asume para aplacar la saturación de los sentidos, situación a la que el sujeto llega ante el exceso de los estímulos cognitivos externos que se ve incapaz de procesar. Es el caso de la visita al Jardín de Luxemburgo, en Ante el monumento a Verlaine, de Crónicas marchitas, después de la visita al Museo. A este espacio "propicio a la meditación y al reposo en medio del ruidoso sacudimiento matinal de París, salía a implorar apaciguamiento para mis nervios, sacudidos tan rudamente por tan intensas emociones; reposo para mis retinas fatigadas, extenuadas, por el incomparable desfile de visiones" (84). 
En Alfonso Daudet en los Campos Elíseos, de Crónicas marchitas, el cronista realiza un callejeo clásico:

\begin{abstract}
He deambulado un poco por las galerías, sonoras como claustros [...] Me he detenido ante los anaqueles de la esquina de la calle Vaugirard [...] Y en seguida, caminando, caminando, he llegado hasta la calle Bonaparte. He doblado, y descendido, curioseando los polvorientos escaparates de los tenduchos [...] me quedo plantado contemplando [...] con qué suma delicadeza, una florista instalaba su pequeño puesto de flores [...] A ellos voy [a los Campos Elíseos], por ahora, con el único, exclusivo objeto de buscar la estatua de Alfonso Daudet [...] Odio los guías [...] Voy escrutando por todos lados. (53-55)
\end{abstract}

Atributos típicos del flâneur en este último caso, son el deambular por las galerías, la atracción ejercida por los escaparates de las tiendas, el callejeo sin rumbo determinado o la atención prestada a los diversos tipos sociales callejeros.

También utilizan la retórica de la flanerie las siguientes crónicas de Marginales de la Vida: Ante los escombros del Nacional, sobre el incendio de un pequeño teatro de la capital salvadoreña: "Esta mañana, ante los escombros, humeantes todavía..." (Ambrogi 1963a: 51) 21. La degollación de los Santos Naranjos, sobre el derribo de estos árboles en el Parque Bolivar (119127) y su continuación Los últimos naranjos del Bolívar (211-217); o La visión del crepúsculo, una maravillosa descripción impresionista del ocaso en la Ciudad de San Salvador (193-198).

De las crónicas de Ambrogi mencionadas por Baldovinos (2008), crónicas que en mayor o menor medida incorporan la mirada del flâneur, se pueden mencionar De paseo. Impresiones y sensaciones, descripción de un viaje en tranvía a los arrabales de El Salvador, donde el centro de atención son los espacios y los tipos sociales humanos (recordemos $L a$ novela del tranvía, de Manuel Gutiérrez Nájera, que asume el mismo tema y la misma mirada), La entrada triunfal, sobre la entrada del ejército victorioso del General Francisco Melendez a la capital salvadoreña, La Semana Santa-crónica momentánea-(recordemos la crónica sobre la Semana Santa en España contemporánea, de Rubén Darío), o Causerie, dedicada a la Noche Buena, donde el cronista declara sentir un placer infinito en rozarse con la multitud y tomar parte en el regocijo callejero, debe el típico baño de multitudes.

\title{
7. Conclusiones
}

La flanerie, mediante el procedimiento de la escena urbana, se encuentra ampliamente consolidada en las crónicas de los más relevantes escritores modernistas.

Sin olvidar las crónicas de Luis G. Urbina, Juan José Tablada o Manuel Díaz Rodríguez, debemos mencionar por último a José Enrique Rodó (1871-1917), cuyas crónicas, la mayoría, aparecieron publicadas poco después de su muerte en El camino de Paros, dedicadas a su 'peregrinaje' europeo. Bremer (2000: 221), al destacar su atemporalidad, se ocupa de diferenciar la intención general de las crónicas de Rodó frente a las de Martí o Darío:

\footnotetext{
Mientras Martí parte en sus crónicas muchas veces de un acontecimiento actual [...] Rodó integra sus experiencias de viaje en una reflexión general, muchas veces casi filosófica. No presenta ni ciudades ni lugares con sus características más o menos turísticas, como lo hace muchas veces Darío en sus crónicas de viaje, así como tampoco algún texto de información actual.
}

Es cierto, Darío asume una mirada turística en España contemporánea o en Peregrinaciones, mientras que Martí parte de hechos de actualidad (el terremoto de Charleston, o la inauguración de la Estatua de la Libertad), para iniciar reflexiones sobre la identidad nacional. En cambio, como señala Bremer (2000: 219), Rodó, como sucede en las crónicas italianas, constata los efectos de la tradición cultural en la cotidianeidad de este último 
país para reflexionar sobre la contribución que este tipo de experiencia podría aportar a la construcción de la identidad cultural y social latinoamericana.

La participación de todos los escritores analizados o mencionados en este artículo en la estética de la flanerie nos permite confirmar la existencia de una consolidada reflexión en los intelectuales latinoamericanos sobre los procesos de la modernidad social y cultural en América Latina, Estados Unidos, el Cercano Oriente y el Extremo Oriente. Julián del Casal asume la mirada decadentista del escritor de espíritu 'aristocrático' que repudia tanto los valores utilitaristas de la sociedad mercantil como las multitudes. Frente a otros flâneurs, que se extasían durante el baño de multitudes, Casal prefiere las calles silenciosas, solitarias, invernales... En ocasiones, cuando asiste a un espectáculo público, la multitud se representa como Otredad de la que es preciso alejarse. El decadentista se encuentra más cómodo en el interior de su hogar.

Por su parte, Martí sitúa sus reflexiones en el marco del debate sobre los valores anglosajones y latinos. Se presenta una dialéctica entre la admiración por el progreso económico estadounidense y la crítica de su afán utilitarista, que excluye la belleza y promueve grandes espacios de miseria en las ciudades. Las observaciones de Martí, como periodista flâneur, se centran tanto en describir las inauguraciones de los símbolos del progreso (Puente de Brooklyn) y de los valores estadounidenses (Estatua de la Libertad) y sus lugares de ocio (Coney Island) como en denunciar la miseria (Por la Bahía de Nueva York), sufrida sobre todo por la población inmigrante.

La flanerie de Nervo asume una mirada de elogio a los espacios de la modernidad burguesa, esquema en el que también participa Gutiérrez Nájera. Son visiones burguesas y pequeñoburguesas, amables, incluso jocosas, sobre la vitalidad de los espacios públicos, sobre todo de aquellos dedicados al consumo. Ambos, junto con Gómez Carrillo, son los cronistas de los bulevares.

Ambrogi, en sus crónicas salvadoreñas, más que elogiar los cambios de la modernidad social y cultural, se dedica a describir, con técnica descriptiva impresionista, la sociabilidad de un apacible y pequeño país centroamericano cuya capital, San Salvador, todavía no se ha convertido en metrópoli. Al igual que en las crónicas de viaje de Gómez Carrillo, Ambrogi se enfrenta en las crónicas de Oriente, en contradicción con sus expectativas, a la occidentalización de esta región del mundo.

\section{Notas}

1. Neumeyer (1999: 17-18) lo plantea como 'paradigma conceptual abierto': "Partiendo de una definición mínima, la de que el flâneur camina través de la ciudad sin dirección y sin objetivo, debe ser considerada esta figura como un 'paradigma abierto'. Como tal, se le suscriben ciertamente atributos sustantivos, pero no hay ningún sitio atemporal del que salga la figura del flâneur, ninguna esencia que se le atribuya validez final, ningún tipo social, con el que se le identifique de manera concluyente. Hay diversas funciones que se pueden asignar al flâneur en los respectivos textos y contextos históricos [...] Debe ser escrita una historia de las funciones desde las que se aprecie al flâneur menos como una autoridad sustancial que como un medio al que se le atribuyen diversas de funciones".

2. Los inicios de la crónica modernista han sido analizados por González (1983) y por Sirkó (1975).

3. Escribió en periódicos como La Discusión o La Habana Elegante. Utilizó pseudónimos como Hernani. 
4. A partir de este momento, y hasta que se indique lo contrario, toda cita de las crónicas de Amado Nervo proviene de la siguiente edición: Nervo, Amado. 1971d. Cuentos y crónicas. México: Universidad Nacional Autónoma de México.

5. A partir de este momento, toda cita de las crónicas de Amado Nervo pertenece a la siguiente edición: Nervo, Amado. 1946. Crónicas. La Plata: Editorial Calomino.

6. Martí publicó sus crónicas en periódicos como La Opinión Nacional, de Caracas, desde 1881 a 1882; La Nación, de Buenos Aires, desde 1882 a 1892, o El Partido Liberal, de México.

7. A partir de este momento, toda cita de la obra de José Martí procede de la siguiente edición: José Martí. 2003. En los Estados Unidos. Periodismo de 1881 a 1892. Madrid: ALCA XX.

8. Martin y Martin (2003) resumen las transformaciones económicas y sociales que experimentó el Estados Unidos en el que vivió Martí, representadas en numerosas crónicas dedicadas al progreso tecnológico e industrial y a las problemáticas sociales.

9. Aunque su aserción es acertada, Ramos, para ejemplificar la crítica del arte incorporado al mercado, no utiliza el mejor ejemplo, ya que describe los espectáculos de una feria en Coney Island. No son ejemplo de arte mercantilizado.

10. Entre los periódicos mexicanos en los que escribió Gutiérrez Nájera se encuentran El Tiempo, El Porvenir, El Monitor, El Liberal, La Voz, El Federalista y El Partido Liberal.

11. A partir de este momento, mientras no se indique lo contrario, toda cita de textos de Gutiérrez Nájera procede de la siguiente edición: Manuel Gutiérrez Nájera. 1940. Cuentos, crónicas y ensayos (Pról. y sel. de Alfredo Maillefert). México: Ediciones de la Universidad Nacional Autónoma.

12. De manera muy similar, y de alguna manera traicionándose con su objetivo, como es el de denunciar la explotación de una clase social, Federido Engels, en el capítulo "Las grandes ciudades", de La situación de la clase obrera en Inglaterra en 1846, se había dedicado, más que a describir la situación de los obreros, a representar las ciudades inglesas como espacios invadidos por la basura.

13. A partir de ahora toda cita de la compilación de cuentos de este autor procede de la siguiente edición: Gutiérrez Nájera, Manuel. 1983. Cuentos completos. México: Fondo de Cultura Económica.

14. El formalismo ruso consideraría esta técnica de extrañamiento (que la narración se focalice desde el punto de vista de alguien o algo distanciado de los acontecimientos o marginal respecto del mundo representado, en este caso un paraguas) como el principal procedimiento que otorga a este cuento su carga de literariedad.

15. En este apartado no hemos incorporado La novela del tranvía, cuento que se integrará en una próxima contribución sobre la flanerie en los medios de transporte.

16. Toda cita de este volumen procede de la siguiente edición: Arturo Ambrogi. 1963b. Sensaciones del Japón y de la China. San Salvador: Ministerio de Educación. Dirección general de Publicaciones.

17. A partir de ahora, toda cita de este libro procede de la siguiente edición: Arturo Ambrogi.1958b. Páginas escogidas. El Salvador, San Salvador: Ministerio de Cultura. 
18. A partir de este momento, toda cita de Crónicas marchitas procede de: Arturo Ambrogi. 1958a. Crónicas marchitas. San Salvador: Ministerio de Cultura.

19. A partir de este momento, toda cita de El libro del trópico procede de la siguiente edición: Arturo Ambrogi.1955a. El libro del trópico. San Salvador: Ministerio de Educación. Dirección general de Publicaciones.

20. A partir de este momento, toda cita de Muestrario procede de la siguiente edición: Arturo Ambrogi. 1955b. Muestrario. El Salvador, San Salvador: Ministerio de Cultura.

21. A partir de este momento, toda cita de Marginales de la vida procede de: Arturo Ambrogi. 1963a. Marginales de la vida. San Salvador: Ministerio de Educación. Dirección general de Publicaciones.

\section{Bibliografía}

Ambrogi, Arturo. 1955a. El libro del trópico. San Salvador: Ministerio de Educación. Dirección general de Publicaciones.

1955b. Muestrario. El Salvador, San Salvador: Ministerio de Cultura.

1958a. Crónicas marchitas. San Salvador: Ministerio de Cultura.

1958b. Páginas escogidas. San Salvador: Ministerio de Cultura.

1963a. Marginales de la vida. San Salvador: Ministerio de Educación. Dirección general de Publicaciones.

1963b. Sensaciones del Japón y de la China. San Salvador: Ministerio de Educación. Dirección general de Publicaciones.

Araya, Pedro. 2003. “Itinerario de un pensamiento”. En: Martí, 1783-1801.

Avilés Ángeles, Ruth. 2006. "La confluencia de géneros literarios en Cuentos frágiles, de Manuel Gutiérrez Nájera”. Escritos. 33: 113-130.

Baudelaire, Charles. 1996. Salones y otros escritos sobre arte (Trad. de Carmen Santos). Madrid: Editorial Visor.

Bremer, Thomas. 2000. “"En este maravilloso suelo de Italia, donde los ojos leen la unidad de una tradición y de un espíritu.' Las crónicas de Rodó y El camino de Paros en el contexto rioplatense del fin de siglo". En: Ottmar Ette y Titus Heydenreich (eds.), 213-222.

Cairo, Ana. 2003. “José Martí y la política en los Estados Unidos”. En: Martí, 1933-1947. 
Cañas, Dionisio. 1994. El poeta y la ciudad. Nueva York y los escritores hispanos. Madrid: Cátedra.

Casal, Julián del. 1964. Prosas. Vol. II. La Habana: Consejo Nacional de Cultura.

2002a. “Agua fuerte. Media noche”. En: Jofre, 205-206.

2002b. "Bajo la lluvia”. En: Jofre, 194-196.

2002c. “Croquis femenino”. En: Jofre, 207-210.

Clay Méndez, Luis Felipe. 1979. Julián del Casal: Estudio comparativo de prosa y poesía. Miami: Editorial Universal.

Cortés-Rocca, Paola. 2009. "La ciudad bajo los ojos del Modernismo". A contracorriente. 7(1): 146-167.

Crary, Jonathan. 2008. Suspensiones de la percepción. Atención, espectáculo y cultura moderna. Madrid: Akal.

Cuvardic García, Dorde. 2009. “La retórica del desastre natural en dos crónicas de José Martí: El terremoto de Charleston y Nueva York bajo la nieve”. Inter.c.a.mbio. Año 6 (7): 189-206.

2010. "La mirada del flâneur frente a la del turista en las crónicas de Enrique Gómez Carrillo". Actas I Congreso Internacional e Interdisciplinario Historias de viajes. Jerez de la Frontera, 1, 2 y 3 junio 2010 (en prensa).

Federman, Joan. 1975. "La visión decadente del mundo en los cuentos y crónicas de Julián del Casal”. En: Jiménez (ed.), 121-134.

Fountain, Anne. 2003. “Autores estadounidenses asumidos por Martí”. En: Martí, 1909-1932.

Gomáriz, José. 2003. "José Martí en las entrañas de la modernidad”. Casa de las Américas. 231: 85-94.

Gómez Carrillo, Enrique. 1921. El encanto de Buenos Aires. Madrid: Mundo Latino.

Gutiérrez Nájera, Manuel. 1940. Cuentos, crónicas y ensayos .Prol. y selec. Alfredo Maillefert. México: Ediciones de la Universidad Nacional Autónoma.

1983. Cuentos completos. México: Fondo de Cultura Económica.

Jiménez, Yvette de Báez (ed.).1997. Varia Lingüística y literaria. 50 años del CELL. III. Literatura: siglos XIX y XX. México: El Colegio de México. 
Jofre, Álvaro Salvador . 2002. El impuro amor de las ciudades. La Habana.

Juan, Adelaida de. 2003. "Arte y entorno en Nueva York según Martí". En: Martí, 1979-1991.

Lagmanovich, David. 2003. "Los Estados Unidos vistos con ojos de nuestra América”. En: Martí, 1848-1861.

Langer, Peter. 1984. "Sociology-Four images of organized diversity: bazaar, jungle, organism, and machine". En: Lloyd Rodwin y Robert M. Hollister (eds.), 97-117.

Lara, Álvaro Darío. 2007. "Influencias modernistas en la crónica urbana de Arturo Ambrogi". Aula Abierta (Suplemento del Diario Co Latino). 15 septiembre (33): 1-3 y 6.

Lloyd Rodwin y Robert M. Hollister (eds.). 1984. Cities of the mind. Images and themes of the city in the social sciences. New York: Plenum Press.

Martí, José. 1946. Obras completas. Volumen II. La Habana: Editorial Lex.

2003. En los Estados Unidos. Periodismo de 1881 a 1892. Madrid: ALCA XX.

Martin, Gail y Gerald Martin. 2003. "Los Estados Unidos en que vivió Martí”. En: Martí, 1802-1847.

Martínez, José Luis. 1997. "Manuel Gutiérrez Nájera: el cronista, el viajero y el periodista”. En: Yvette Jiménez de Báez (ed.), 209-223.

Martínez, José María; René Ibarra; Hilda Salazar y Luis Eduardo Campuzano. 2008. "Biografía, hibridez literaria, elitismo social y modernismo en algunas crónicas desconocidas de Manuel Gutiérrez Nájera". Anales de Literatura Hispanoamericana, 37: 161-203.

Mesonero Romanos, Ramón de. 1967. Escenas matritentes. Barcelona: Editorial Bruguera.

Montero, Óscar. 1993. Erotismo y representación en Julián del Casal. Amsterdam: Rodopi.

Morán, Francisco. 2005. "Volutas del deseo: hacia una lectura del orientalismo en el modernismo Hispanoamericano". MLN. 120(2): 383-407.

2006. "'En el rayón lleno de espejos': Enrique Gómez Carrillo en la tienda por departamentos de la escritura modernista". Anclajes. 10: 141-155.

Nervo, Amado. 1946. Crónicas. La Plata: Editorial Calomino.

1971. Cuentos y crónicas. México: Universidad Nacional Autónoma de México. 
Olivio Jiménez, José (ed.). 1975. Estudios críticos sobre la prosa modernista hispanoamericana. New York: Eliseo Torres and Sons.

Ottmar Ette y Titus Heydenreich (eds.). 2000. José Enrique Rodó y su tiempo. Frankfurt am Main: Vervuert.

Peña, Luis H. y Magdalena Maiz. 1988. "La discreción exquisita: una aproximación a las crónicas de Gutiérrez Nájera”. Texto Crítico. 14 (38): 43-50.

Ramos, Julio. 2003. Desencuentros de la modernidad en América Latina. Literatura y política en el siglo XIX. Santiago de Chile: Editorial Cuarto Propio/Ediciones Callejón.

Rodríguez, Pedro Pablo. 2003. "El fantasma de Banquo. El problema social en las escenas norteamericanas. Apuntes para un estudio”. En: Martí, 1948-1977.

Roque Baldovinos, Ricardo. 2008. "Para una filosofía del hecho menudo". Centroamericana. 15: $57-86$.

Rotker, Susana. 2003. "Intérprete de dos mundos. Las crónicas de José Martí y la prensa norteamericana”. En: Martí, 1862-1880.

2005. La invención de la crónica. México: Fondo de Cultura Económica.

Shulman, Ivan A. 2003. "Textualizaciones sociales y culturales del proyecto moderno martiano: las crónicas norteamericanas”. En: Martí, 1881-1905.

Sirkó, Oksana María. 1975. "La crónica modernista en sus inicios: José Martí y Manuel Gutiérrez Nájera”. En: Olivio Jiménez (ed.), 57-73. 